\title{
AN INNOVATIVE RESPONSE TO COMMERCIAL UAV MENACE - ANTI-UAV FALCONRY
}

\author{
Slavimir S. Nikolić* \\ Educons University - Sremska Kamenica, \\ Faculty for Applied Security Studies, Republic of Serbia
}

\begin{abstract}
$\Lambda \mathrm{s}$ law enforcement agencies and military are on the lookout for Inew efficient ways in tackling proliferation of menacing commercial UAVs, the innovative practice of anti-UAV falconry referred as LowTech solution to a High-Tech problem appears as the effective adaptation or alternative to the set of existing anti-UAV solutions. The comparative analysis of the trained birds of prey physiology against technical specifications of common commercial present UAVs indicates supremacy of the avian hunters versus potentially hostile UAVs as per efficiency of their neutralization and safe processing. While anti-UAV falconry idea came as the result of advances in commercial UAV technology followed by increasing capacity of their untoward or hostile use its much wider operational use is not likely. However, it attracts due attention of the law enforcement as availing noteworthy advantages within urban environments that cannot be matched with application of currently available anti-UAV solutions - thus representing a valid operational asset in the common response to growing commercial UAV menace.
\end{abstract}

Key Words: anti-UAV, commercial, drone, eagles, falconry, hostile, police, safety, security, threat

\section{Introduction}

In the era of evolving security challenges and asymmetric threats, security services, law enforcement agencies and the military are on the lookout for new developments in the field of innovative approaches to counter-intelligence and their forces, inviolable premises and critical infrastructure protection from the unrelenting proliferation ${ }^{1}$ and consequent security menace of the unauthorized or potentially hostile commercial UAVs (Unmanned Aerial Vehicle).

\footnotetext{
* The views expressed in this article are solely those of the author while the presented research has been undertaken using information and material available and originating exclusively from open sources.

${ }^{1}$ Some revenues projections on drone sales estimate that it would top USD 12 billion in 2021, up from just over USD billion in 2015; http://www.businessinsider.com/uk-funds-drone-trials-around-the-world-2016-12
} 
Beyond a broader approach in tackling potential UAV security threats via embedding no-fly-zone codes in their avionics, legislation and registration, owner's civic education or yet stern practices of electromagnetic spectrum jamming, laser use, use of the bazookalike net guns or specially equipped UAVs against unwanted aerial rovers, this research article aims to provide insight into the subject of intuitive application of the low-tech approach to ease rising disquiet originating from the expansion of the commercial UAVs the anti-UAV falconry.

The use of animals to assist in performing security-related tasks is not new, but dates back several thousand years in history. The first defensible records of humans using birds of prey for hunting comes from an Assyrian bas-relief, which dated at the early part of the seventh century B.C. or that of the same practice in China as early as 680 B.C. ${ }^{2}$. While United Kingdom's national counter-intelligence and security agency (MI5) had been known to use trained peregrine falcons during WWII to intercept Nazi homing courier pigeons ${ }^{3}$, post WWII period had not witnessed palpable practice of bird use in conducting any of the specific tasks previously known to be associated with them - until most recently, in the Netherlands, where Dutch National Police has joined forces with private enterprises to train one of the biggest existing avian raptors, hunter eagles ${ }^{4}$, to intercept, attack and take unwanted drones from the skies.

Aiming to closely describe this innovative and interesting practice in fighting proliferation and growing insecurity originating from the use of tactical commercial drones, the author will first examine bona fide use of the commercial UAVs and security related threats that aerial vehicles are estimated to represent today. After insight into history and current instances of animals' use in security services, the author will emerge into origins and examination of anti-UAV falconry initiated by the Netherlands police including the comparative analysis of two modern adversaries of the skies, i.e. birds' physiology and UAV's technical characteristics. After a look at current spread of the anti-UAV falconry practice, the second chapter until the end will pay due attention to safety concerns related to the use of birds of prey in the fight against commercial UAVs.

This research is not aimed at praising the anti-UAV falconry, but at providing space to better understand where it comes from, what it encompasses and what the comparative advantages of this innovative approach are in tackling the ever increasing risks of the commercial UAV menace today and in the conceivable near future. Such development is expected to increasingly feature momentous threats to our common safety and security with further technological advancement and proliferation of cheaper and more capable commercial UAVs and their growing potential hostile use.

\footnotetext{
2 Ancient \& Medieval Falconry: Origins \& Functions in Medieval England by Shawn E. Carroll, http://www.r3.org/richard-iii/15th-century-life/15th-century-life-articles/ancient-medieval-falconry-originsfunctions-in-medieval-england/

${ }^{3}$ Airborne threat of Nazi pigeons, http://news.bbc.co.uk/2/hi/special_report/1999/01/99/wartime_spies/263333.stm, The Nazi pigeon and British peregrine Falcon War (1940-1942), http://strangevehicles.greyfalcon.us/Nazi\%20Pigeon.htm, Ml5 Report on Carrier Pigeons in WWII, http://www.arcre.com/archive/pigeons/pigeonsmi5

${ }^{4}$ Eagle is the common name for many large birds of prey of the family Accipitridae. It belongs to several groups of genera that are not necessarily closely related to each other. Most of 60 species of eagles are from Eurasia and Africa. Outside this area just 14 species can be found - two in North America, nine in Central and South America and three in Australia; https://en.wikipedia.org/wiki/Eagle
} 


\section{The bona fide use of the tactical commercial UAVs}

The understanding that new technologies ranging from a variety of devices, machines, robots, or, increasingly software packages, allow people better and faster exercise of various tasks or solving problems and, in general, enhance human efficiency - the UAV industry has become nowadays more and more diverse, innovative and international, carrying the enormous potential for growth with the associated possibility to create jobs and grow economy.

Despite already versatile use, their proven overall benefit had not still been fully explored, only proving to have the capacity that can significantly improve our lives and eliminate risks we are being exposed to via hi-end technology use.

UAVs or drones have already become almost vital in conducting tasks of search and rescue, visual inspections, surveillance and reconnaissance, science and research activities, safety and security related tasks, education, sensory identification, aerial video and photography, GIS surveying and mapping, unmanned cargo transport, news reporting, monitoring business activities, marketing, gaming, sporting, entertaining, and tasks that involve detection of land mines, healthcare, delivery of medications, blood or items required for urgent medical assistance, disaster response, meteorology, combatting wild fires or deforestation, farming and agriculture, ranching, ${ }^{5}$ not to forget their law enforcement (police) and military use.

Today researches and inventors add lights, sound, cameras, microphones, sensors, robotic arms, wave cancellation or wave enhancement technologies to drones. We fly them or they are being flown by 'themselves' lowly or highly, silently or noisily, supervisibly or totally invisibly. They are our best friends, and increasingly our worst enemies. ${ }^{6}$

\section{Safety and Security Threats of Tactical Commercial Drones}

Commercial UAVs are being increasingly observed as a new threat to national and wider aspects of safety and security. The popularity of the recreational and unsafe, ill-guided or even illegal use of a variety of available and increasingly cheaper commercial UAVs expands rapidly, introducing a host of the new security concerns that alarm security experts worldwide.

\section{Aviation Safety and Security Concerns}

The International Air Transport Association (IATA) has warned that civilian drones are becoming a real and growing threat to the safety of commercial aviation. ${ }^{7}$ The IATA has called for implementation of regulations before any serious accident occurs, stating that there is a significant number of pilot reports of drones where they were not expected

\footnotetext{
5 See interesting compilation, but not an exhaustive list at: http://www.futuristspeaker.com/businesstrends/192-future-uses-for-flying-drones/

${ }^{6}$ lbid.

${ }^{7}$ Civilian drones threaten safety of commercial aviation: IATA, http://www.businessinsurance.com/article/00010101/STORY/160219877/Civilian-drones-threaten-safety-ofcommercial-aviation-IATA
} 
to be, particularly at low altitudes around airports. ${ }^{8}$ During the period August 2015 to January 2016, the U.S. Federal Aviation Administration (FAA) reported 583 separate drone incidents of sorts despite the fact that the majority of the incidents were minor, where pilots or bystanders reported drones flying in restricted airspace without necessarily endangering anyone. ${ }^{9}$ Since consequences of a too close encounter ${ }^{10}$ or potential airborne collision between a commercial UAV and an airplane would have a catastrophic outcome, controlling drones more efficiently and reducing the threat originating from them over airspace is an ongoing battle for civil aviation authorities.

On a positive note, during 2015 the FAA made great steps towards integrating drones into the nation's airspace. The first big step took place at the end of 2014, when a new web-based drone registration system went online, enabling registration of more than 616,000 owners and individual drones. As a result, those registered drone operators now have the basic aviation knowledge to keep themselves and their friends and neighbors safe when they fly their assets. ${ }^{11}$ Similarly to the U.S., in the European Union (EU) in August 2016 the European Commission published the first draft on subject regulations the Prototype Commission Regulation on Unmanned Aircraft Operations and its Explanatory Note ${ }^{12}$ - in order to provide a clearer idea of what the EU regulation and safety rules for civil drone use could be. The introduction of civilian drone regulations is expected to palpably contribute to the increased control over commercial UAVs use.

\section{The Contemporary Safety and Security Concerns}

If used without gaining the basic knowledge of these specific aerial systems, and not in accordance with the established safety guidelines and operating rules, or even further, being used with clearly untoward intentions or ultimate goals, drones today bear a significant safety and security challenge. There are multiple representative examples of potentially hostile UAVs being found in inviolable areas of urban, peaceful and civic environments.

One commercial UAV crashed into the grounds of the U.S. presidential home in January $2015^{13}$, triggering an immediate lockdown of the White House. In the other case, a Japanese man flew the commercial drone carrying radioactive sand onto the roof of the Japanese Prime Minister office in April 2015, protesting over the Japanese government nuclear energy policy (the landing drone triggered a security alert and raised fears of extremists using drones to carry out attacks). ${ }^{14}$ According to the media reports, some

\footnotetext{
${ }^{8}$ Ibid.

${ }^{9}$ FAA Releases Updated UAS Sighting Reports, https://www.faa.gov/news/updates/?newsld=85229

${ }^{10}$ Close encounters and sightings of drones, https://www.bloomberg.com/news/articles/2016-04-04/dronesare-the-new-threat-to-airline-safety

${ }^{11}$ Drone Registration Marks First Anniversary, https://www.faa.gov/news/updates/?newsld=87049

${ }^{12}$ European Aviation Safety Agency, 'Prototype' Commission Regulation on Unmanned Aircraft Operations, https://www.easa.europa.eu/system/files/dfu/UAS\%20Prototype\%20Regulation\%20final.pdf

13 Small drone crash (White House), http://www.reuters.com/article/us-usa-whitehouse-deviceidUSKBNOKZOUD20150126

${ }^{14}$ Japan radioactive drone: Tokyo police arrest man, http://www.bbc.com/news/world-asia-32465624
} 
15 commercial UAV flights have been reported over or in close proximity to French nuclear power plants so far, leaving authorities both in unease and disquiet, ${ }^{15}$ further increasing concerns about unidentified commercial UAVs flying above Paris, its attractions, the U.S. Embassy, French military installations and even the official residence of the President of France (Palais de l'Elysée). ${ }^{16}$

It is not rare in the U.S. for people to use their personal firearms against UAVs in line with understanding that they represent a well-defined form of the invasion of individual privacy [analogous to physical trespassing] ${ }^{17}$ whereas data that UAVs could collect or eventually avail are increasingly susceptible to hacking and extraction. Hence, the more sensitive data they can 'collect', the more serious potential problem and risk with their unsolicited use is.

However, the most disturbing fact on potential untoward UAV use nowadays is that their bodies (fuselage) could be easily fitted with a firearm, ${ }^{18}$ a location (GPS) emitter or a miniature laser-designation device, ${ }^{19}$ an explosive charge, ${ }^{20}$ or could even deliver a piece of explosive ordnance from the heights. ${ }^{21}$ As drones could be used and/or controlled by hostile elements, such possibilities rise reasonable and snowball disquiet along with the already proven potential of the commercial UAVs to be intensively used by either criminals $^{22}$ or terrorists. ${ }^{23}$ Tactical commercial drones had already become the tool that authorities find quite difficult to detect and stop $^{24}$ using perceptibly limited capacities of observation practices or related detection and sensory technological solutions.

Extending the potential threat of unsolicited or ill-managed UAV use by an additional [huge] step further, the particular research and experiment ${ }^{25}$ was initiated in 2010 at Massachusetts Institute of Technology (MIT) in the U.S. that provides an additional level of concern on potential hostile UAV utilization. It refers to the operations of swarming autonomous commercial drones - those able to fly in formation, navigate without being

\footnotetext{
${ }^{15}$ Drones survolant des centrales nucléaires, http://www.lexpress.fr/actualite/societe/drones-survolant-descentrales-nucleaires_1619292.html , La centrale nucléaire de Golfech, en France, survolée par un drone, http://www.lexpress.fr/actualite/societe/la-centrale-nucleaire-de-golfech-en-france-survolee-par-undrone_1776417.html

16 Intercepter un drone? "Moins évident que d'arrêter une voiture", http://lexpansion.lexpress.fr/hightech/intercepter-un-drone-moins-evident-que-d-arreter-une-voiture_1655127.html

17 Kentucky man shoots down drone hovering over his back garden, http://arstechnica.co.uk/techpolicy/2015/07/kentucky-man-shoots-down-drone-hovering-over-his-backyard/

${ }^{18}$ Gun Strapped To A Flying Drone, https://youtu.be/e_EHQM7YgkQ

${ }^{19}$ Potentially acting as, or becoming a beacon or homing device (for aerial attack).

${ }^{20}$ Pentagon Confronts a New Threat From ISIS: Exploding Drones, http://www.nytimes.com/2016/10/12/world/middleeast/iraq-drones-isis.html

${ }^{21}$ See Hezbollah Drone Drops Bombs On Syrian Rebel Positions, https://www.youtube.com/watch?v=F9CqOfE_mHM

${ }^{22}$ Criminals using drone to smuggle record quantity of drugs to prisoners crash it inside jail after losing control, http://www.mirror.co.uk/news/uk-news/criminals-using-drone-smuggle-record-8810596

${ }^{23}$ WATCH: Syrian Terrorist Builds Armed Drone, http://heavy.com/news/2016/09/jund-al-aqsa-al-qaedaarmed-drone-building-twitter-video/

${ }^{24}$ Criminals, Terrorists Find Uses for Drones, Raising Concerns, http://www.wsj.com/articles/criminalsterrorists-find-uses-for-drones-raising-concerns-1422494268

${ }^{25}$ Project Perdix, https://beaverworks.Il.mit.edu/CMS/bw/projectperdixcapstone
} 
remotely controlled, and even able to sense each other. ${ }^{26}$ It did not take long for this technology to attract the attention of the U.S. Department of Defense (DoD) with these drones being capable to analyze their operational environment, react to changes in their surroundings and act almost intelligibly with regards to their programmed tasking. As expected, the DoD has militarized the project and successfully demonstrated use of autonomous swarming drone(s) in May 2016 (Navy's LOCUST) and October $2016^{27}$ (PERDIX). China followed through with their own swarming drones demonstration in December $2016,{ }^{28}$ and Russia speeded up their [first immediate] response to such potentially grave security menace - introducing military grade UAV repellent system - Репеллент. ${ }^{29}$

Concerns are more than reasonable with hi-tech achievements extremely susceptible to untoward proliferation when speaking about possible hostile use of this, or similar, new generation of UAVs. Such an example involving a swarm of commercial drones could envisage their use to conduct multi - angle observation of sensitive targets, drones being used for multitarget laser designation, or acting as false radar reflections that could confuse military air defense mechanisms (trigger radar jamming, i.e. interference). There is the growing potential for developments as described above to offer to both legitimate soldiers and belligerents of the digital era a totally new line of - very difficult to confront - attack vector(s) opportunities.

Clearly, all the points referred to above indicate that there is a growing concern associated with the proliferated use of the unregulated or uncontrolled commercial drones, in particular with regard to the fast-moving industry and unavoidably rising potential threat to people's safety, security and lives - in particular having in mind their upsetting harmful use potential.

\section{Animals in Safety and Security Services}

The pioneering ways in which animals were used during WWI and WWII including their law enforcement related use could hardly receive endorsement as per [animal] ethics since they were either turned into remotely controlled explosive assets, ${ }^{30}$ or used as vehicles for spreading contagious and deadly biological agents. ${ }^{31}$ Besides this particular combat use, driven by circumstances of the time, animals from mammals to birds have been used throughout the last world war(s) by law enforcement officers as time-honored tradition or means of logistics support, medical evacuation, movement or explosive devices sensors, communication enabling tool, for exercise of reconnaissance or (counter) intelligence tasks and being such for boosting the troop's morale.

\footnotetext{
${ }^{26}$ Featuring pre-programmed behavior, pattern fly program, or target action.

${ }^{27}$ Department of Defense Announces Successful Micro-Drone Demonstration, https://www.defense.gov/News/News-Releases/News-Release-View/Article/1044811/department-of-defenseannounces-successful-micro-drone-demonstration

${ }^{28}$ Fixed-wing UAV Swarm Prototype of Skywalker X6, http://diydrones.com/profiles/blogs/fixed-wing-uavswarm-prototype-of-skywalker-x6 ; If Drone Swarms Are the Future, China May Be Winning, http://www.popularmechanics.com/military/research/a24494/chinese-drones-swarms/

${ }^{29}$ Вражеские беспилотники убьют «Репеллентом», http://izvestia.ru/news/653954

${ }^{30}$ Anti-tank dog, https://en.wikipedia.org/wiki/Anti-tank_dog, Противотанковая собака (подвижные мины), http://army.armor.kiev.ua/engenear/sobaka-mina.shtml

${ }^{31}$ Biological weapon, Biological weapons in the World Wars, https://www.britannica.com/technology/biological-weapon
} 
Nowadays animals continue to be used both in battlefield and law enforcement, as well as increasingly in specific civic environs, where their most regular use today refers specifically to trained dogs, ${ }^{32}$ mules and horses, ${ }^{33}$ camels, $^{34}$ dolphins ${ }^{35}$ and sea lions. ${ }^{36}$ While birds have not been recently used like other animals, the practice of using predator birds such as eagles, hawks and falcons has been observed since 2000 in providing an additional degree of air safety at both commercial and military-NATO airports in North America. The company in Canada, Falcon Environmental Services, ${ }^{37}$ has a commercial contract with several airport authorities both in the U.S. and Canada to help ${ }^{38}$ police airspace by using predator birds during periods between take-off and landing of airplanes, practicing falconry to scare bird flocks (their natural prey) before potentially colliding with propellers and jet engines ${ }^{39}$ and initiating a tragedy.

Using birds of prey to protect planes in flight appeared to be a successful business model that can enhance safety and security of the airspace. As a result, a quite innovative approach appeared in an attempt to counter the menace of commercial UAVs proliferation and their largely unpoliced use. It happened on the other side of the Atlantic with a similar avian predators' training company that found its potential clientele within the Dutch National Police Force. ${ }^{40}$

\section{The Examination of Anti-uav Falconry \\ The Origins - Guard From Above (GFA)}

The innovative and interesting connection between falconry and the much needed response to increasing drones' safety and security menace took place in 2015 when the Dutch National Police initiated the collaboration with the Guard From Above (GFA), ${ }^{41}$ the

\footnotetext{
${ }^{32}$ Working as sentries, detecting land mines and bombs, and performing search, rescue, and recovery tasks; http://www.libraryindex.com/pages/2203/Service-Animals-MILITARY-SERVICE.html

${ }^{33}$ Today traditionally used by law enforcement mounted units. However, they are also used by the US Army Special Forces soldiers in Afghanistan since the very beginning of the US involvement there, since they navigate the mountainous terrain there much easier in places that are not otherwise accessible except on foot. http://www.scpr.org/news/2014/03/02/42534/role-of-police-on-horseback-has-changed-over-time/ http://www.usatoday.com/story/news/nation/2014/06/22/horses-marines-afghanistan/10744395/

${ }^{34}$ Camel cavalry, http://www.wikiwand.com/en/Camel_cavalry

${ }^{35}$ Trained to alert to suspicious objects underwater, protecting ships and harbors, a dolphin can sniff out a mine, give heads up to its crew, then leave the device like an acoustic transponder to lead divers to the weapon's location; http://www.takepart.com/photos/animals-serve-war/dolphins

${ }^{36}$ They have been used for bomb detection. Their speed underwater makes them especially good at defending against terrorist swimmers. Reaching speed up to $25 \mathrm{mph}$, sea lions can sneak up on suspicious swimmers before they are aware, and using their bite, place a clamp on the swimmer so they can be picked up; http://www.takepart.com/photos/animals-serve-war/sea-lions

${ }^{37}$ Falcon Environnemental Services, http://www.falconenvironmental.com/

${ }^{38}$ Aside other measures applied, see for insight: Bird Control Group at http://birdcontrolgroup.com/aviation/ , Strategies for Prevention of Bird-Strike Events at http://www.boeing.com/commercial/aeromagazine/articles/2011_q3/4/ or, Bird control at airports at http://www2.vlieghinder.nl/naslagdocs/CDrom/REGELS_SCHIPHOL/2.3_TNL/4.3.4.1_Bird_control_at_airports.pdf

${ }^{39}$ How Falcons Protect Planes From Gulls and Geese, https://www.wired.com/2011/11/st_birdbouncers/

${ }^{40} \mathrm{CNN}$, Dutch cops train eagles to hunt drones, http://edition.cnn.com/2016/02/02/europe/dutch-drones-eagles/

${ }^{41}$ GFA press release, http://guardfromabove.com/wp-content/uploads/2016/01/NL-ENG-Guard-From-AbovePress-Release-FAQ.pdf
} 
birds of prey [Dutch: roofvogels] training security firm, to keep dangerous drones from causing havoc by grabbing them out of the sky. ${ }^{42}$

The anti-UAV falconry project, which the GFA's chief executive officer describes as "a low-tech solution for a high-tech problem", the first known of its kind in the world, examined drone related incidents and viable contra drone (C-UAV) solutions since 2014, with a particular mission of using birds of prey to intercept hostile drones. ${ }^{43}$ Joining efforts with its potential clientele $^{44}$ and the common goal to make airspace drone-safe, this company focused its work on assessing how possible drone threats could impact their clients' assets, while providing training to personnel that would handle the GFA trained birds. ${ }^{45}$ The company conducted its field test work at the former Valkenburg Naval Air Base military airfield in the Netherlands. ${ }^{46}$

Acknowledging that their anti-UAV falconry attention is focused on $5 \%$ of drone users, the percentage assessed by the company to be a group with plausibly untoward intentions, the GFA's use of birds of prey to intercept hostile drones always starts with a threat analysis involving one of the locations prone to the threat of drones, and then (if positive) select the best combination of contra drone solutions. ${ }^{47}$ The Dutch National Police, being one of the important clients of the GFA, uses their service for on-site solutions to counter drones. Such venue could be a major public event, a VIP visit, or places as sensitive as airports - where the GFA trained bird of prey can take down potentially hostile drone trespassing security environs that have to be 'sterile', or 'inviolable' ones.

The representative real-life examples of such threat scenario could be the ones where pilots reported drones flying in the dangerous proximity of airplanes, ${ }^{48}$ or that of the appearance of a commercial drone which flew above the packed football stadium. ${ }^{49}$ In each case, public safety and security were potentially at stake, triggering last years' Dutch National Police decision to undertake a less technological approach to counter unsolicited drone use.

\section{The Comparative Analysis - Falcons vs. UAVs}

The comparative analysis of technical specifications of the most common or widespread tactical commercial drone of today ${ }^{50}$ against the physiology of the GFA-trained birds of prey (a bald eagle) reveals the supremacy of the live hunter versus its mechanical prey. The sheer speed and power of these animals when put next to one of commercial drones is unmatchable.

\footnotetext{
${ }^{42}$ Eagle-eyed: Dutch police to train birds to take down unauthorized drones, https://www.theguardian.com/world/2016/feb/01/dutch-netherlands-police-birds-unauthorized-drones

${ }^{43}$ Guard From Above, http://guardfromabove.com/about-us/

${ }^{44}$ GFA mostly works for international governmental security agencies, police and defense forces.

${ }^{45}$ Source ibid to footnote 37.

${ }^{46}$ Dutch Firm Trains Eagles to Take Down High-Tech Prey: Drones, http://www.nytimes.com/2016/05/29/world/europe/drones-eagles.html?_r=1

${ }^{47}$ How we use birds of prey to intercept hostile drones, http://guardfromabove.com/how-we-intercept-drones/

${ }^{48}$ Most recently at New York's JFK airport in August 2016 or London's Heathrow in November 2016.

${ }^{49}$ As above 30,000 person capacity stadium during the Union of European Football Associations (UEFA) Euro 2016 football qualifying match in Belgrade, Serbia in October 2014.

${ }^{50}$ Being the DJI's Phantom 4 Pro type quadcopter; DJI Phantom 4 Pro, http://www.dji.com/phantom-4-pro/info\#specs
} 
Eagles' maximum flight speed of some 120 to $160 \mathrm{~km} / \mathrm{h}$, possible flight altitude from 3 to $4.5 \mathrm{~km}$, wing span of 1.8 to $2.3 \mathrm{~m}$, vision four to eight times better than humans' and ability to detect movement up to $3.2 \mathrm{~km}$ distance, claws big enough to fit into a tennis ball, talons $5 \mathrm{~cm}$ long and powerful enough to penetrate flesh or crush bones, and lift power confirmed by snatching animals as big as young lambs (estimate up to $15 \mathrm{~kg}$ of weight) degrade every single technical specification of the adversary drone. ${ }^{51}$ Having a low flying commercial UAV able to develop maximum flight speed of $72 \mathrm{~km} / \mathrm{h}$, its $30 \mathrm{~cm}$ width / length and $20 \mathrm{~cm}$ of height, weight of some $2 \mathrm{~kg}$ and maximum flight time on single battery less than 30 min cannot represent a comparable opponent to the instinctdriven [and in addition, purposely and specifically trained] avian predator observing and understanding buzzing drone as just one of its every day unprotected prey.

Indeed, [trained] eagles see and react to drones as they would to their normal prey, grabbing them mid-air and taking them immediately to a safe place on the ground, ${ }^{52}$ where there are no other animals or people. Further, the GFA eagle trainers attest that eagles appear to be normally suspicious about drones, as they tend to demonstrate aggressive avian behavior seeing them as potentially other birds of prey (i.e. a competition) - thus triggering the eagles' hostile interaction against the drone, further enforced by avian logic of defending their territory from another bird of prey. ${ }^{53}$

Comparing anti-UAV falconry against other currently known anti-UAV measures, either kinetic actions, energy propagation measures or ['cannibalistic'] tackling of potentially hostile UAVs by other UAVs, anti-UAV falconry demonstrates several particular superior qualities in the domain of efficiency of drone neutralization and their safe processing.

Firstly, eagles are proven to have 'onboard equipment' unparalleled to that of drones, as shown in previous paragraphs. Secondly, trained predators' action always brings [lands] any attacked drone safely to the ground rather than causing them to crash down either vertically or through ballistic curve movement, which can pose a significant safety risk. Without exemption, none of the other anti-UAV methods that exist today is capable of preventing the drone ending up haphazardly in the crowd of bystanders or VIPs. However, application of other anti-UAV measures could easily get the job done safely in inhabited or rural environments. Thirdly, if deployed strategically on standby at high-risk locations or areas aimed to be protected from possible intrusion of the unauthorized drones, trained falcons are able to spot, intercept and bring down a standard tactical commercial drone within moments of its take-off . Fourthly, the biological skills of birds of prey, as extensively documented in the GFA demonstrations conducted so far, make sure that there is a very low percentage of 'failed' attacks or targets missed by these UAV predators.

While mimicking a predatory act over drones eagles always hit their targets in the middle of their 'back', i.e. their upper side, exactly between the rotors. Furthermore, it appears that birds' vision is such that it allows them to actually see the rotors of the drone, whereas human vision is such that provides us only with a blur image, or hollow

\footnotetext{
${ }^{51}$ Eagle anatomy details taken from 'Bald Eagles, Dudley, Karen (1997)

${ }^{52}$ Multiple GFA-produced demonstration videos show that eagles are taking drones to a location designated by trainers.

${ }^{53}$ According to Geoff LeBaron of (US) National Audubon Society, interviewed in early 2016 by the Guardian. See 'Eagle-eyed: Dutch police to train birds to take down unauthorized drones', https://www.theguardian.com/world/2016/feb/01/dutch-netherlands-police-birds-unauthorized-drones
} 
space. Observers of the falcon's anti-UAV training state that birds are constantly hitting drones in such a way that they do not get injured by the rotors and have no trouble avoiding them. ${ }^{54}$

Finally, as drone flying is an activity which vastly depends on winds speed and direction, which makes their maneuvering difficult both for a hostile drone operator and the operator of anti-UAV, ${ }^{55}$ this factor is for birds of prey only a facilitating one, being a multiplier of their flying skills. Huge predator birds are known to be able to use the existing wind conditions to extremes to enhance their natural flight sharpness and the might of the attack.

\section{The Limitations of Anti-UAV Falconry}

However, the Dutch and other above-mentioned National Police entities would probably not focus their anti-UAV enforcement efforts in the manner that would bypass parallel and possibly wider use of the already existing and available directed-energy or kinetic type of solutions. The use of trained birds of prey in fight against proliferation of potentially hostile commercial UAVs would be expected to develop further in limited practice due to a number of actually significant restricting factors. Those include, but are not restricted to: significant costs incurred in their operation, complexity of the system, its low mobility factor, vulnerability of the birds within hostile environments, expected increase of the threat category accompanied with untoward drones ahead, and unstoppable technological advancements that are to provide anti-UAV systems, which would be more effective, cheaper and, to be expected, with more versatile capabilities in addressing the drones menace.

New systems have already appeared with ability of 'beam' UAVs safe on the ground somehow similar to that observed with avian raptors exercise - either via disabling or hijacking their control and featuring a net-launching or net-grabbing capability. Moreover, anti-UAV falconry would not be of substantial assistance in confrontation scenarios involving large numbers of the swarming commercial UAVs used with hostile intention, where more adequate applicable countermeasures would be those involving directed-energy anti-UAV solutions.

\section{The Dutch Exercise}

Instead of immediately resorting to a variety of already known effective anti-drone solutions, ranging from either shooting down a potentially hostile drone (a 'kinetic' solution), taking them down using radio jamming guns or high-end anti-drone laser 'death rays' devices (applying directed-energy UAV countermeasures), or grabbing them from the

\footnotetext{
${ }^{54}$ According to National Audubon Society's Geoff LeBaron. See article https://www.theguardian.com/world/2016/feb/01/dutch-netherlands-police-birds-unauthorized-drones

${ }^{55}$ Suppose the use of this methodology to neutralize a potentially hostile UAV.

${ }^{56}$ Anti-drone 'death ray' can blast vehicles out of the sky from a mile away, https://www.theguardian.com/technology/2015/oct/07/drone-death-ray-device-liteye-auds; Battelle DroneDefender, Directed-energy Unmanned Aircraft System Countermeasure, http://www.battelle.org/ourwork/national-security/tactical-systems/battelle-dronedefender, Drone-hunting lasers developed for US Navy, http://www.telegraph.co.uk/technology/10935201/Drone-hunting-lasers-developed-for-US-Navy.html
} 
skies with nets fired from specialized launchers or even from the net equipped UAVs ${ }^{57}$ (referred to as 'robotic UAV falconry'), the Dutch National Police approach to 'natural' solution to drone menace showed an effective adaptation and alternative to use of those, only conditionally called, 'harder' options.

Having concerns about drones being used for criminal purposes and following a reported increase in the number of drone incidents, the Dutch National Police looked into avian raptors as possible solution for situations where drones should not be allowed to fly. Those range from incidental situations of air ambulances being prevented by drones from conducting their urgent tasks, drones flying in restricted airspace and too close to airports, or their use over crowds of people, such as activities where VIP or dignitaries' visits could be jeopardized by incoming hostile drone. The scenario equal to latter was demonstrated to public in Dutch National Police practical exercise conducted in September 2016, ending with a successful commercial UAV killed by their trained eagle. ${ }^{58}$

Having conducted a successful one-year research and trial project with the GFA trained avian raptors with a success rate of bringing down $80 \%$ of drones, the Dutch National Police consequently purchased a number of trained drone hunter eagles and put them in operational use in several locations across the country - becoming the first police force in the world using such enforcement practice for unwanted drones. Necessarily, an adequate number of police agents with an affinity to work with these police birds were drafted to undertake a specialized falconry training within the GFA services package; a bird handler training program for international governmental police and security agencies, which will work with birds of prey on a daily basis. ${ }^{59}$ Eventually, the Dutch National Police intends to engage up to 100 police officers for these tasks. ${ }^{60}$ Being committed to using eagle UAV hunters, the Dutch police even began raising their own sea eagle chicks. It expects to have their own flying 'squad' trained in hunting drones by summer $2017 .^{61}$

\section{Anti-UAV Falconry Spreading Further}

After the world premiere of anti-drone falconry in safety and security service, the promising results from the Dutch exercise attracted the attention of the British Scotland Yard, which was also potentially interested in making use of this innovative UAV policing tactics. ${ }^{62}$ Apparently, the Scotland Yard and the head of the London's Metropolitan Police, Sir Bernard Hogan-Howe, observed this exercise and took great interest in the

\footnotetext{
${ }^{57}$ Watch Japan's Police Drone Catch a Quadcopter, http://www.popsci.com/watch-japans-police-drone-catchquadcopter

${ }^{58}$ Politie traint roofvogels om drones te onderscheppen, https://www.politie.nl/nieuws/2016/september/13/politie-traint-roofvogels-om-drones-te-onderscheppen.html

${ }^{59}$ GFA Certified Birdhandler Training Program, http://guardfromabove.com/services/

${ }^{60}$ Dutch police use eagles to hunt illegal drones, http://www.pbs.org/newshour/bb/dutch-police-use-eagleshunt-illegal-drones/

${ }^{61}$ Ibidem.

${ }^{62}$ Police In London Are Considering Using Eagles To Take Down Drones, https://www.buzzfeed.com/patricksmith/the-long-beak-of-the-law?utm_term=.ul6jalGDNv\#.yf2xlw2P1j
} 
achievements of the Dutch National Police, not excluding the fact that Britain may soon start training and employing eagles in battle against unwanted drones and making London safer. ${ }^{63}$

The UK had already experienced cases of unwanted drone use and sees them as a potential threat to safety and security. It sees drones as a potential threat to safety and security, not only with regards to threats to aviation operations, but also to criminal and terrorist activities. The drone carrying mobile phones, SIM cards and drugs was already found on the grounds of Strange ways Prison in Manchester in November $2015^{64}$, while a person has been convicted in the UK for drone misuse in September 2015, flying a drone over Premier League football match venues. ${ }^{65}$

While the British have only indicated their mere interest in this innovative anti-UAV practice, the French Air Force follows the Dutch ways of thinking and followed in their footsteps. In November 2016 they demonstrated their very own UAV eagle hunter, allegorically named D'Artagnan ${ }^{66}$ in their Base 118 in Mont-de-Marsan. The French Air Force avails four trained UAV eagle hunters so far, which they acquired in mid-2016; they are reportedly still in the experimental phase of the project ${ }^{67}$. If successful, it could be expected that the French would introduce anti-UAV falconry into operational use similar to that of the Dutch. On the related note, the French Ministry of Defense has already launched an appeal for offers of new concepts in interception and neutralization of potentially hostile drones. Additionally, the French National Research Agency (I'Agence nationale de la recherche) has even allocated a one million EUR budget to advance research on this subject. ${ }^{68}$

\section{Avian Safety Concerns}

The GFA and Dutch National Police are both engaged in evaluating this anti-UAV avian force, being cautious of the fact that drones' blades, especially 3D printed ones or those made of carbon fiber, could seriously injure or even kill trained hunter birds. Despite their biological supremacy and natural hunting instincts, as elaborated here, this particular bird safety concern of animal protection and welfare groups goes further to

\footnotetext{
${ }^{63}$ Saviour birds: Danish bird-training company inspires London to train eagles that take down drones, http://www.ibtimes.com.au/saviour-birds-danish-bird-training-company-inspires-london-train-eagles-take-downdrones-video

${ }^{64}$ Drone carrying drugs found in prison grounds at HMP Manchester, http://www.bbc.com/news/uk-englandmanchester-34764417

65 This Guy Just Got Convicted Of Illegally Flying Drones Over Landmarks And Stadiums, https://www.buzzfeed.com/patricksmith/drone-crime?utm_term=.feGNzgQr4w\#.IhLBoG15JK ; A case somehow similar to one of Serbia's UEFA football match of October 2014 mentioned earlier, though not anything similar to severity of the former.

${ }^{66}$ French Air Force eagle demonstrates drone-hunting skill to Holland, https://www.rt.com/viral/372945french-eagle-drone-hunt/

${ }^{67}$ Ibidem.

68 Intercepter un drone? "Moins évident que d'arrêter une voiture", http://lexpansion.lexpress.fr/hightech/intercepter-un-drone-moins-evident-que-d-arreter-une-voiture_1655127.html
} 
their disapproval of bald eagles' preying on any flying objects. Apparently, their staple diet would be fish and carrion, hence assertion has been made that birds are being trained for doing something not natural for them at all - or even not having any cognitive awareness of what drones are. ${ }^{69}$ Finally, criticism $^{70}$ had been directed at human interference with animal species that only a decade ago they were taken off the Endangered Species List. ${ }^{71}$

While bald eagle legs are naturally encrusted, which protects them against potential bites or injuries from their prey, and their claws are sharp and have a grip strong enough to crush a bone, the GFA trainers and handlers are now considering creation of specific protection for their animal hunters, an armor-like 'leg or claw protector glove' that would prevent them from being harmed by the rotating blades of the UAVs. This practice would be particularly welcomed in likely scenarios when their trained eagles could be engaged against the larger commercial drones. However, experiences gathered so far in the domain of anti-UAV falconry do not indicate any reports of birds being hurt in the process. The Dutch National Police itself confirmed that none of the eagles were hurt in the process; but, as for the drones, none of them survived. ${ }^{72}$

\section{Conclusion}

Since timely detection and effective neutralization of the untoward commercial drones becomes a more daring task today, whereas finding the drone operator(s) is virtually impossible, this article explored unique characteristics [or a tradecraft signature] of the anti-UAV falconry applied by the Dutch National Police, pending potentially further operational application by the British and French law enforcement. It depicts most recent police and military experiences in exercising anti-UAV falconry that avails operational advantage in scenarios where it is too dangerous to use more conventional countermeasures, which would commonly cause disabled drones to fall on the ground and injure people or induce damage.

While anti-UAV falconry is likely not to develop more significantly in operational use due to its specific restrictive factors, experiences and lessons learned show it avails a noteworthy application benefits within the urban environment that currently cannot be matched with application of other available countermeasures. Moreover, in times when untoward and potentially significantly hostile groups and individuals are increasingly experimenting with and harnessing new UAV technologies, and unsolicited or hostile commercial UAVs use increasingly threatens both general safety and security, and that of inviolable and sensitive environs.

\footnotetext{
${ }^{69}$ Kent Knowles, president of the Raptor Conservancy of Virginia. See: Let's Not Force Eagles to Fight Rogue Drones, http://news.nationalgeographic.com/2016/02/160206-eagle-drone-video-rogue-dutch-policedanger-hunting-robot0/

${ }^{70}$ Ibidem.

${ }^{71}$ Bald Eagles Soar off Endangered Species List, But Will Act Be Weakened? http://news.nationalgeographic.com/news/2007/06/070628-bald-eagles.html

${ }^{72}$ Eagles away! Dutch police unveil latest recruits against drones, https://www.yahoo.com/tech/eagles-awaydutch-police-unveil-latest-recruits-against-144952235.html
} 
Accordingly, it could be concluded that crowdsourcing of the best available practices in providing most efficient, practical and adaptable response(s) to threat of commercial UAVs would be the most adequate approach that is a common solution to increasing risks of the UAV menace, UAV-born hazards and associated criminal behavior, including violent, destructive or terrorism-related acts. In that sense, anti-UAV falconry [Low-Tech] approach to an existing commercial UAV [High-Tech] problem unarguably keeps its proved response capability within the family of currently available anti-UAV solutions' arsenal.

\section{Bibliography}

[1] "Perdix" Mini Air-Launched Swarming UAV,

http://www.americanmilitaryforum.com/forums/threads/perdix-mini-air-launched-swarming-uav.579/

[2] 192 Future Uses for Flying Drones, http://www.futuristspeaker.com/business-trends/192future-uses-for-flying-drones/

[3] 20 great UAV applications areas for Drones, https://air-vid.com/20-great-uav-applications-areas-drones/

[4] 3DR Collaborates With AirMap Because Flying A Drone Can Be Hazardous,

https://techcrunch.com/2015/11/17/3dr-collaborates-with-airmap-because-flying-a-drone-can-be-hazardous/

[5] A Swarm of Nano Quadrotors, https://www.youtube.com/watch?v=YQIMGV5vtd4

[6] Airborne threat of Nazi pigeons,

http://news.bbc.co.uk/2/hi/special_report/1999/01/99/wartime_spies/263333.stm

[7] AirMap, https://www.airmap.com/

[8] Airports get creative to combat threat of bird strikes, http://www.usatoday.com/story/travel/flights/2013/04/01/airports-plane-bird-strikes/2043411/

[9] Albania and Serbia face UEFA sanctions after abandoned 'drone' game, https://www.theguardian.com/football/2014/oct/15/albania-charged-uefa-serbia

[10] Albania awarded 3-0 win after Serbia match abandoned over drone stunt, https://www.theguardian.com/football/2015/jul/10/albania-serbia-match-abandoned-drone

[11] Albania drone arrest before Serbia Euro 2016 qualifier, http://www.bbc.com/news/world-europe-34464856

[12] American anti-drone rifle deployed in Iraq, Tactical cyberwar against ISIS, http://www.popsci.com/american-anti-drone-rifle-spotted-in-iraq

[13] Ancient \& Medieval Falconry: Origins \& Functions in Medieval England, by Shawn E. Carroll, http://www.r3.org/richard-iii/15th-century-life/15th-century-life-articles/ancient-medieval-falconryorigins-functions-in-medieval-england/

[14] Anti-drone 'death ray' can blast vehicles out of the sky from a mile away, https://www.theguardian.com/technology/2015/oct/07/drone-death-ray-device-liteye-auds

[15] Anti-tank dog, https://en.wikipedia.org/wiki/Anti-tank_dog

[16] Are drones the next target for hackers, http://www.bbc.com/future/story/20140206-can-drones-be-hacked

[17] Are horses still used in the US military? https://www.quora.com/Are-horses-still-used-in-the-US-military

[18] Autonomous drones learn to fly as a flock, https://www.youtube.com/watch?v=uY01pczwwd0

[19] Bald Eagle No Longer Endangered, But in the Clear? http://www.natureworldnews.com/articles/12779/20150217/bald-eagle-no-longer-endangered-butin-the-clear.htm 
[20] Bald Eagles Soar off Endangered Species List, But Will Act Be Weakened? http://news.nationalgeographic.com/news/2007/06/070628-bald-eagles.html

[21] Battelle Fielding 100 Drone Zappers to Pentagon, Homeland Security, https://www.defensetech.org/2016/05/16/battelle-fielding-100-drone-zappers-to-pentagonhomeland-security/

[22] Battelle's DroneDefender anti-drone beam gun grounds UAVs, http://newatlas.com/battelles-dronedefender-beam-gun-uavs/39885/

[23] Bird control at airports,

http://www2.vlieghinder.nl/naslagdocs/CDrom/REGELS_SCHIPHOL/2.3_TNL/4.3.4.1_Bird_control _at_airports.pdf

[24] Bird Control Group, http://birdcontrolgroup.com/aviation/

[25] Canon à eau et brouillage: face aux drones, l'Etat prépare sa riposte, http://www.leparisien.fr/faits-divers/canon-a-eau-et-brouillage-face-aux-drones-l-etat-prepare-sariposte-04-03-2015-4574561.php

[26] China's Missile Swarms vs. America's Lasers, Drones and Railguns: Who Wins?, http://nationalinterest.org/blog/the-buzz/chinas-missile-swarms-vs-americas-lasers-dronesrailguns-who-16303

[27] China's New Fleet Of Drones: Airshow Displays The Future Of Chinese Warbots And Swarms,

[28] Civil Drones (RPAS), https://www.youtube.com/watch?v=5Xs_eVx4nuw

[29] Civil drones in the European Union, Briefing, October 2015, http://www.europarl.europa.eu/RegData/etudes/BRIE/2015/571305/EPRS_BRI(2015)571305_EN.pdf

[30] Civil drones in the European Union, http://www.europarl.europa.eu/thinktank/en/document.html?reference=EPRS_BRI(2015)571305

[31] Close encounters of the drone kind: near-collisions with UAVs increasing, https://www.theguardian.com/business/2015/dec/11/drones-close-encounters-increasing-bard-study-finds

[32] Commercial Uses for Drones, http://www.dronesfutureskies.com/commercial-use\#!dronedelivery-and-automation

[33] Criminals using drone to smuggle record quantity of drugs to prisoners crash it inside jail after losing control, http://www.mirror.co.uk/news/uk-news/criminals-using-drone-smuggle-record-8810596

[34] Department of Defense Announces Successful Micro-Drone Demonstration, https://www.defense.gov/News/News-Releases/News-Release-View/Article/1044811/departmentof-defense-announces-successful-micro-drone-demonstration

[35] Developing European safety rules for civil drones, http://ec.europa.eu/growth/sectors/aeronautics/rpas_en

[36] DJl is updating its drones so they won't fly in restricted airspace, http://www.theverge.com/2015/11/17/9751484/dji-no-fly-zone-geofencing

[37] DoD Announces Successful Micro-Drone Demonstration, https://www.americanmilitaryforum.com/forums/threads/dod-announces-successful-micro-dronedemonstration.1793/\#post-9673

[38] Drone carrying drugs found in prison grounds at HMP Manchester, http://www.bbc.com/news/uk-england-manchester-34764417

[39] Drone Catcher System for Removing the Intruding Drones, https://www.youtube.com/watch?v=jvdKNBSWPyU

[40] 'Drone' crash lands in White House grounds, http://www.telegraph.co.uk/news/worldnews/northamerica/usa/11370087/Drone-crash-lands-inWhite-House-grounds.html 
[41] Drone may have been involved in suspicious death of police horse, http://www.telegraph.co.uk/news/uknews/law-and-order/11986847/Drone-may-have-beeninvolved-in-suspicious-death-of-police-horse.html

[42] Drone Proliferation: The New Threat to National Security, https://www.linkedin.com/pulse/drone-proliferation-new-threat-national-security-joe-thomas-mba

[43] Drone swarms will change the face of modern warfare, http://www.wired.co.uk/article/drone-swarms-change-warfare

[44] Drone-hunting eagles can snatch devices out of the sky, http://www.cbsnews.com/news/drone-hunting-eagles-can-snatch-the-devices-out-of-the-sky/

[45] Drone-hunting lasers developed for US Navy, http://www.telegraph.co.uk/technology/10935201/Drone-hunting-lasers-developed-for-US-Navy.html

[46] Drones - Another threat to security, http://techgenix.com/drones-another-threat-security/

[47] Drones Are Beginning to Pose a Real Threat to Flight Safety Says FAA Data, http://time.com/3608494/faa-near-collisions-planes-drones/

[48] Drones Are the New Threat to Airline Safety, https://www.bloomberg.com/news/articles/2016-04-04/drones-are-the-new-threat-to-airline-safety

[49] Drones au-dessus de Paris, http://www.lexpress.fr/actualite/societe/fait-divers/drones-surparis_1655193.html

[50] Drones becoming 'real' threat to commercial aviation, http://www.nation.co.ke/business/Tech/Drones-becoming-real-threat-to-commercialaviation/1017288-3077238-17phjez/index.html

[51] Drones Gone Rogue to Be Taken down by Eagles in Holland, http://www.valuewalk.com/2016/02/dutch-police-drone-vs-eagles/

[52] Drones have met their match: Portable 'gun' uses radio pulses to halt aircraft mid-air, http://www.dailymail.co.uk/sciencetech/article-3275820/Drones-met-match-Portable-gun-usesradio-pulses-halt-aircraft-mid-air.html\#ixzz4Ud0h1G4M

[53] Drones malveillants: de nouvelles parades expérimentées par l'État d'ici à fin mars, http://www.lefigaro.fr/actualite-france/2015/03/04/01016-20150304ARTFIG00181-dronesmalveillants-de-nouvelles-parades-experimentees-par-I-etat-d-ici-la-fin-mars.php

[54] Drones survolant des centrales nucléaires, http://www.lexpress.fr/actualite/societe/dronessurvolant-des-centrales-nucleaires_1619292.html

[55] Dutch cops train eagles to hunt drones, http://edition.cnn.com/2016/02/02/europe/dutch-drones-eagles/

[56] Dutch Firm Trains Eagles to Take down High-Tech Prey: Drones, http://www.nytimes.com/2016/05/29/world/europe/drones-eagles.html?_r=1

[57] Dutch police are fighting drones with eagles, http://www.telegraph.co.uk/technology/2016/02/01/dutch-police-are-fighting-drones-with-eagles/

[58] Dutch police are training eagles to take out drones, http://www.theverge.com/2016/2/1/10884586/drone-vs-eagle-dutch-police

[59] Dutch Police Deploy Drone-Disabling Birds of Prey, http://www.livescience.com/53586-raptors-disable-dutch-drones.html

[60] Dutch Police Train Eagles to Take down Drones, http://www.discovery.com/dscovrd/wildlife/dutch-police-train-eagles-to-take-down-drones/

[61] Dutch police training eagles to attack drones, http://globalnews.ca/news/2490312/watch-dutch-police-training-eagles-to-attack-drones/ 
[62] Dutch police use eagles to hunt illegal drones,

http://www.pbs.org/newshour/bb/dutch-police-use-eagles-hunt-illegal-drones/

[63] Dutch police use eagles to hunt illegal drones, https://www.youtube.com/watch?v=00szWWrTNnE

[64] Dutch police's drone-hunting eagles are ready for action, http://newatlas.com/dutch-police-eagles-drones/45398/

[65] Eagle Kills Drone, https://www.youtube.com/watch?v=vdgvlHH3JSA\&spfreload=5

[66] Eagle versus drone! Video shows Dutch police training birds of prey to take down aircraft in mid-air, http://www.dailymail.co.uk/sciencetech/article-3426614/Eagle-versus-drone-Video-shows-Dutchpolice-training-birds-prey-aircraft-mid-air.html\#ixzz4UTOrMV8C

[67] Eagles away! Dutch police unveil latest recruits against drones, https://www.yahoo.com/tech/eagles-away-dutch-police-unveil-latest-recruits-against-144952235.html

[68] EASA 'Prototype' Commission Regulation on Unmanned Aircraft Operations, Explanatory Note, https://www.easa.europa.eu/system/files/dfu/Explanatory $\% 20$ Note $\% 20$ for $\% 20$ the $\% 20$ UAS $\% 20$ Prot otype\%20regulation\%20final.pdf

[69] EASA, A-NPA 2015-10, Introduction of a regulatory framework for the operation of drones, https://www.easa.europa.eu/document-library/notices-of-proposed-amendment/npa-2015-10

[70] EASA, Civil drones (Unmanned aircraft), https://www.easa.europa.eu/easa-and-you/civil-drones-rpas

[71] EASA, Concept of Operations for Drones, A risk based approach to regulation of unmanned aircraft, https://www.easa.europa.eu/system/files/dfu/204696_EASA_concept_drone_brochure_web.pdf

[72] EASA, Opinion of a technical nature, Introduction of a regulatory framework for the operation of unmanned aircraft, https://www.easa.europa.eu/document-library/opinions/opinion-technical-nature

[73] EASA, Proposal to create common rules for operating drones in Europe, https://www.easa.europa.eu/system/files/dfu/205933-01-

EASA Summary $\% 20$ of $\% 20$ the $\% 20$ ANPA.pdf

[74] Etats-Unis: l'usage militaire des drones et le risque d'une guerre sans fin, http://www.lexpress.fr/actualite/monde/amerique-nord/etats-unis-l-usage-militaire-des-drones-et-lerisque-d-une-guerre-sans-fin_1554877.html

[75] European Aviation Safety Agency (EASA) 'Prototype' Commission Regulation on Unmanned Aircraft Operations,

https://www.easa.europa.eu/system/files/dfu/UAS\%20Prototype\%20Regulation\%20final.pdf

[76] European Commission, Mobility and Transport, Air, Drone infographics: A look into the aviation of the future, http://ec.europa.eu/transport/modes/air/drones-infographics_en

[77] Eyes in the Sky: A Short History of Bird Spies, http://www.audubon.org/news/eyes-sky-short-history-bird-spies

[78] FAA News, Federal Aviation Administration, Washington, DC 20591, June 21, 2016, Summary of Small Unmanned Aircraft Rule (Part 107), https://www.faa.gov/uas/media/Part_107_Summary.pdf

[79] FAA regulations for commercial drones are now in effect, http://www.theverge.com/2016/8/30/12707502/drone-regulations-legality-us-faa

[80] FAA Releases Updated UAS Sighting Reports, https:/www.faa.gov/news/updates/?newsld=85229

[81] FAA, Press Release - New FAA Rules for Small Unmanned Aircraft Systems Go Into Effect, August 29, 2016, https://www.faa.gov/news/press_releases/news_story.cfm?newsld=20734

[82] FAA, Unmanned Aircraft Systems, https://www.faa.gov/uas/

[83] Face aux drones invasifs, les nouvelles armes de l'Etat, http://www.lexpress.fr/actualite/societe/face-aux-drones-invasifs-les-armes-de-l-etat_1657953.html 
[84] Fact Sheet: Natural History, Ecology, and History of Recovery, Bald Eagle, https://www.fws.gov/midwest/Eagle/recovery/biologue.html

[85] Falcon Environmental Services, http://www.falconenvironmental.com/

[86] Falconry training and technique, https://en.wikipedia.org/wiki/Falconry_training_and_technique

[87] Falconry Used to Secure North American Airports, http://news.nationalgeographic.com/news/2003/03/0325_030325_falconry.html

[88] Falconry, a living human heritage, http://www.unesco.org/culture/ich/en/RL/falconry-a-living-human-heritage-01209

[89] Falcons at New York's JFK Airport Join the Flock of the unemployed, http://www.wsj.com/articles/SB10001424052748704071704576277213052018084

[90] Fears ISIS could use drones for terror bombings in Britain as Government reveals they do same in Syria and Iraq, https://www.thesun.co.uk/news/1519921/fears-isis-could-use-drones-forterror-bombings-in-britain-as-government-reveals-they-do-same-in-syria-and-iraq/

[91] Fifteen Animals That Went To War, http://www.iwm.org.uk/history/15-animals-that-went-to-war

[92] Five Unstoppable Drone Security Threats You Should Be Aware Of, http://www.makeuseof.com/tag/unstoppable-drone-security-threats-aware/

[93] Fixed-wing UAV Swarm Prototype of Skywalker X6, http://diydrones.com/profiles/blogs/fixed-wing-uav-swarm-prototype-of-skywalker-x6

[94] Fixed-wing UAV Swarm Prototype | 固定翼无人机集群试验原型, https://www.youtube.com/watch?v=TjYUTdHKdUg

[95] Foreign Policy, Watch Dutch Police Train Eagles to Catch Flying Drones, http://foreignpolicy.com/2016/02/01/watch-dutch-police-train-eagles-to-catch-flying-drones/

[96] French Air Force eagle demonstrates drone-hunting skill to Hollande, https://www.rt.com/viral/372945-french-eagle-drone-hunt/

[97] French Air Force eagle demonstrates drone-hunting skill to Hollande (VIDEO), https://www.rt.com/viral/372945-french-eagle-drone-hunt/

[98] French Air Force to use eagles against rogue drones, https://www.rt.com/news/367419french-eagles-rogue-drones/

[99] Friendly "Gremlins" Could Enable Cheaper, More Effective, Distributed Air Operations, http://www.darpa.mil/news-events/2015-08-28

[100] Guard From Above, http://guardfromabove.com/

[101] Guard from Above, http://guardfromabove.com/

[102] Guard From Above, Services, http://guardfromabove.com/services/

[103] Hacking Drones and the Dangers It Presents, http://www.npr.org/2012/07/08/156459939/hacking-drones-and-the-dangers-it-presents

[104] Holland's drone-hunting eagles are ready to fly, http://www.theverge.com/2016/9/13/12900596/netherlands-drone-hunting-eagles

[105] How Falcons Protect Planes From Gulls and Geese, https://www.wired.com/2011/11/st_birdbouncers/, https://www.wired.com/video/how-falconsprotect-planes-from-gulls-and-gee

[106] How Russia's Military Plans to Counter the Pentagon's Drone Swarms, http://nationalinterest.org/blog/the-buzz/how-russias-military-plans-counter-the-pentagons-drone19014?page $=2$

[107] http://www.popsci.com/chinas-new-fleet-drones-zhuhai-2016-airshow-displays-futurechinese-warbots-and-swarms 
[108] If Drone Swarms Are the Future, China May Be Winning, http://www.popularmechanics.com/military/research/a24494/chinese-drones-swarms/

[109] Intercepter un drone? "Moins évident que d'arrêter une voiture", http://lexpansion.lexpress.fr/high-tech/intercepter-un-drone-moins-evident-que-d-arreter-unevoiture_1655127.html

[110] ISIS could use drones to drop bombs or chemical weapons on British targets after terror group use them in Syria warns senior security expert, http://www.dailymail.co.uk/news/article3713075/Fears-ISIS-use-DRONES-launch-terror-attacks-Britain.html\#ixzz4Tod0tcjd

[111] ISIS is expanding the reach and sophistication of its drone fleet, http://www.marinecorpstimes.com/story/military/tech/2016/04/17/islamic-state-drones-targetamerican-coalition-forces/83096864/

[112] Japan radioactive drone: Tokyo police arrest man, http://www.bbc.com/news/world-asia-32465624

[113] Kent Knowles, president of the Raptor Conservancy of Virginia. See: Let's Not Force Eagles to Fight Rogue Drones, http://news.nationalgeographic.com/2016/02/160206-eagle-dronevideo-rogue-dutch-police-danger-hunting-robot0/

[114] Kentucky man shoots down drone hovering over his back garden, http://arstechnica.co.uk/tech-policy/2015/07/kentucky-man-shoots-down-drone-hovering-over-his-backyard/

[115] La centrale nucléaire de Golfech, en France, survolée par un drone, http://www.lexpress.fr/actualite/societe/la-centrale-nucleaire-de-golfech-en-france-survolee-par-undrone_1776417.html

[116] L'armée de l'air entraîne des aigles à intercepter des drones, http://www.lexpress.fr/actualite/societe/l-armee-de-l-air-entraine-des-aigles-a-intercepter-desdrones_1851542.html

[117] Le gouvernement s'attaque à l'usage des drones, http://www.la-croix.com/Ethique/Actualite/Le-gouvernement-s-attaque-a-l-usage-des-drones-201503-04-1287344

[118] Let's Not Force Eagles to Fight Rogue Drones, http://news.nationalgeographic.com/2016/02/160206-eagle-drone-video-rogue-dutch-policedanger-hunting-robot0/

[119] LOCUST, https://www.youtube.com/watch?v=AyguXoum3rk\&feature=youtu.be

[120] LOCUST: Autonomous, swarming UAVs fly into the future, https://www.onr.navy.mil/Media-Center/Press-Releases/2015/LOCUST-low-cost-UAV-swarm-ONR.aspx

[121] Major air disaster narrowly averted over London after drone nearly collides with passenger plane near the Shard, https://www.thesun.co.uk/news/2200187/major-air-disaster-narrowlyaverted-over-london-after-drone-nearly-collides-with-passenger-plane-near-the-shard/

[122] Meet the Falcons Keeping North American Runways Safe, http://www.citylab.com/commute/2016/05/falconry-bird-strikes-airports/484424/

[123] MI5 Report on Carrier Pigeons in WWII, http://www.arcre.com/archive/pigeons/pigeonsmi5

[124] Micro drones, Areas of Application, https://www.microdrones.com/en/applications/

[125] Military animal, https://en.wikipedia.org/wiki/Military_animal

[126] Military Horses \& Mules in Afghanistan, http://olive-drab.com/od_army-horses-mules_afghanistan.php

[127] Military use of animals, http://www.animal-ethics.org/military-use-animals/

[128] Net Gun Drone - Excipio, Flite Test, https://www.youtube.com/watch?v=LgWIm5zrY4w

[129] New horsepower for war zones: Special Forces saddle up, http://www.usatoday.com/story/news/nation/2014/06/22/horses-marines-afghanistan/10744395/ 
[130] New Russian electromagnetic weapon will paralyze combat drones, http://rbth.com/defence/2016/11/23/new-russian-electromagnetic-weapon-will-paralyze-combatdrones_650293

[131] Nine Military Animals, http://www.takepart.com/photos/animals-serve-war/sea-lions

[132] Passenger plane approaching Heathrow 'in near-miss with drone 650ft to the east of the Shard', http://www.telegraph.co.uk/news/2016/11/17/passenger-plane-approaching-heathrow-had-nearmiss-with-drone-65/

[133] Pentagon Battle-Tests Micro Drone Swarm, http://www.technewsworld.com/story/84217.html

[134] Pentagon Confronts a New Threat From ISIS: Exploding Drones, http://www.nytimes.com/2016/10/12/world/middleeast/iraq-drones-isis.html

[135] Pentagon Tests 'Drone Swarm' Super Weapon, https://warisboring.com/pentagon-testsdrone-swarm-super-weapon-2029e0d8fb1b\#.amy8ccnvi

[136] Perdix Drones Are the Riskiest Things Coming Out of the Pentagon, https://www.inverse.com/article/26103-perdix-autonomous-drone-swarm

[137] Pigeon photography, https://en.wikipedia.org/wiki/Pigeon_photography

[138] Plusieurs drones encore repérés au dessus de Paris, http://www.lefigaro.fr/actualitefrance/2015/03/04/01016-20150304ARTFIG00064-plusieurs-drones-encore-reperes-au-dessusde-paris.php

[139] Police are using eagles to take out rogue drones,

http://www.cnbc.com/2016/02/02/police-are-using-eagles-to-take-out-rogue-drones.html

[140] Police in London Are Considering Using Eagles to Take down Drones, https://www.buzzfeed.com/patricksmith/the-long-beak-of-thelaw?utm_term=.ul6jalGDNv\#.yf2xlw2P1j

[141] Politie traint roofvogels om drones te onderscheppen, https://www.politie.n//nieuws/2016/september/13/politie-traint-roofvogels-om-drones-te-onderscheppen.html

[142] Politie traint roofvogels om drones te onderscheppen, https://www.politie.n//nieuws/2016/september/13/politie-traint-roofvogels-om-drones-te-onderscheppen.html

[143] Project Perdix, https://beaverworks.II.mit.edu/CMS/bw/projectperdixcapstone

[144] Robots that fly ... and cooperate, https://www.youtube.com/watch?v=4ErEBkj_3PY

[145] Russia Touts Drone Swarms and Electromagnetic Cannon for Sixth-Gen Fighter, http://defensetech.org/2016/07/13/russia-touts-drone-swarms-and-electromagnetic-cannon-forsixth-gen-fighter/

[146] Russian 6th-gen drone fighter jets to fly in swarms, enter near space, https://www.rt.com/news/350736-russian-fighter-jets-drone-swarm/

[147] Russian Army to get weapons to fight mini-drone swarms in two years, http://tass.com/defense/921400

[148] Save the Eagles International, http://savetheeaglesinternational.org/

[149] Saviour birds: Danish bird-training company inspires London to train eagles that take down drones, http://www.ibtimes.com.au/saviour-birds-danish-bird-training-company-inspires-london-traineagles-take-down-drones-video

[150] Service Animals - Law Enforcement, http://www.libraryindex.com/pages/2200/ServiceAnimals-LAW-ENFORCEMENT.html

[151] Short Teaser Guard From Above, HD, Birds of prey to intercept hostile drones, https://www.youtube.com/watch?v=Vd00zh4NGcc 
[152] Si les drones attaquent... les centrales nucléaires,

http://www.lexpress.fr/actualite/societe/si-les-drones-attaquent-les-centrales-

nucleaires_1633095.html

[153] SkyWall 100: An anti-drone bazooka, http://arstechnica.com/gadgets/2016/03/skywallanti-drone-bazookal

[154] SkyWall, Capture Drones - Protect Assets, http://openworksengineering.com/skywall

[155] SkyWall: SkyWall100 Drone Defence System - A Man Portable and Cost Effective Counter Drone System, https://www.youtube.com/watch?v=M6tT1GapCe4

[156] Small drone crashes on White House grounds, operator comes forward, http://www.reuters.com/article/us-usa-whitehouse-device-idUSKBNOKZOUD20150126

[157] So, Dutch Cops Are Teaching Majestic Eagles to Hunt Drones, https://www.wired.com/2016/02/so-dutch-cops-are-teaching-majestic-eagles-to-hunt-drones/

[158] Stadion Partizana, https://sh.wikipedia.org/wiki/Stadion_Partizana

[159] Strategies for Prevention of Bird-Strike Events,

http://www.boeing.com/commercial/aeromagazine/articles/2011_q3/4/

[160] Syrian Terrorist Builds Armed Drone, http://heavy.com/news/2016/09/jund-al-aqsa-alqaeda-armed-drone-building-twitter-video/

[161] The Ancient Art of Keeping Birds at Bay, https://www.youtube.com/watch?v=a9mCtGC3RJc

[162] The Dogs of War: Beloved Comrades in Afghanistan, http://www.nytimes.com/2011/05/12/world/middleeast/12dog.html

[163] The FAA logged more than 500 drone incidents in six months, http://www.theverge.com/2016/3/25/11306850/faa-drone-airport-incidents

[164] The History of Pigeon Camera Photography, http://twistedsifter.com/2012/05/history-ofpigeon-camera-photography/

[165] The laser designator-equipped Shadow UAV offers smart bombs more precision, http://www.homelandsecuritynewswire.com/laser-designator-equipped-shadow-uav-offers-smartbombs-more-precision

[166] The Nazi pigeon and British peregrine Falcon War (1940-1942), http://strangevehicles.greyfalcon.us/Nazi\%20Pigeon.htm

[167] The Pentagon just tested drones that can attack an enemy like a swarm of killer bees, http://www.businessinsider.com/pentagon-test-mini-drone-swarm-2017-1

[168] The threat of drones on the safety of civil aviation, http://www.1001crash.com/indexpage-drone-lg-2.html

[169] Thesis UAV Solutions, Anti-Drone Net System, http://www.uasvision.com/2016/01/20/anti-drone-net-system/

[170] This Device Turns Any Gun into an Anti-Drone Ray, http://www.popsci.com/dronedefender-is-an-anti-drone-rifle-attachment

[171] This drone catches other drones by shooting nets at them, http://www.telegraph.co.uk/technology/news/12093204/This-drone-catches-other-drones-byshooting-nets-at-them.html

[172] This Guy Just Got Convicted of Illegally Flying Drones over Landmarks and Stadiums, https://www.buzzfeed.com/patricksmith/drone-crime?utm_term=.feGNzgQr4w\#.IhLBoG15JK

[173] Tiny Spy Drones No Match for Russia's 'Repellent-1' Mobile Anti-Drone Complex, https://sputniknews.com/military/201612291049110110-repellent-anti-drone-complex-development/ 
[174] Tokyo metro police to use nets to snare suspicious craft, http://asia.nikkei.com/PoliticsEconomy/Policy-Politics/Tokyo-metro-police-to-use-nets-to-snare-suspicious-craft

[175] Tokyo police unveil net-wielding interceptor drone, http://www.theverge.com/2015/12/11/9891128/tokyo-interceptor-net-drone

[176] Two airliners fly within 100 feet of drone above New York, http://edition.cnn.com/2015/08/01/us/drone-airliner-jfk/

[177] UK funds drone trials around the world, http://www.businessinsider.com/uk-funds-dronetrials-around-the-world-2016-12

[178] UNESCO Nomination file No. 01209, http://www.unesco.org/culture/ich/en/RL/falconry-aliving-human-heritage-01209

[179] UNESCO, Lists of Intangible Cultural Heritage and the Register of Best Safeguarding Practices, http://www.unesco.org/culture/ich/en/lists

[180] Unmanned aerial vehicle, https://en.wikipedia.org/wiki/Unmanned_aerial_vehicle

[181] Unmanned Aircraft Systems, https://www.faa.gov/uas/

[182] US Research Company Battelle Developed Counter UAV Beam Rifle "Drone Defender", https://www.youtube.com/watch?v=d9Zvpx9fFsM

[183] Video appears to confirm use of attack drones by Hezbollah,

http://www.timesofisrael.com/video-appears-to-confirm-use-of-attack-drones-by-hezbollah-in-syria/

[184] VIDEO. Sécurité, vie privée, législation: les drones, une menace?,

http://lexpansion.lexpress.fr/high-tech/ces-drones-hors-de-controle_1655211.html

[185] War Culture - Animals of war,

https://www.military-history.org/articles/war-culture-animals-of-war.htm

[186] Watch Japan's Police Drone Catch a Quadcopter, http://www.popsci.com/watch-japanspolice-drone-catch-quadcopter

[187] Watch this drone being live hacked, http://www.wired.co.uk/article/drone-hack-defcon

[188] Watch This Insane Video of an Eagle Trained to Hunt Drones,

http://time.com/4202469/dutch-police-eagle-drones/

[189] Welcome to the arms race for anti-drone weaponry,

http://www.theverge.com/2015/10/29/9631208/drone-defender-regulation-iacp

[190] Wereldprimeur: politie zet roofvogels in om drones uit te schakelen,

https://www.politie.nl/nieuws/2016/januari/31/wereldprimeur-politie-zet-roofvogels-in-om-dronesuit-te-schakelen.html

[191] What Happens if a Drone Gets Sucked Into a Jet Engine? Results Might Surprise You!, https://vimeo.com/144401420

[192] What is Falconry?, http://www.n-a-f-a.com/?page=What_is_Falconry

[193] White House security breach shifts debate on civilian drones,

http://www.biznews.com/briefs/2015/01/27/white-house-security-breach-shifts-debate-civilian-drones/

[194] World War I in Photos: Animals at War, http://www.theatlantic.com/photo/2014/04/worldwar-i-in-photos-animals-at-war/507320/

[195] World War One, https://www.bl.uk/world-war-one/articles/animals-and-war

[196] Вражеские беспилотники убьют «Репеллентом», http://izvestia.ru/news/653954

[197] Противотанковая собака (подвижные мины),

http://army.armor.kiev.ua/engenear/sobaka-mina.shtml 